NBER WORKING PAPER SERIES

\title{
HOUSEHOLD DEMAND FOR LOW CARBON PUBLIC POLICIES: EVIDENCE FROM CALIFORNIA
}

\author{
Matthew J. Holian \\ Matthew E. Kahn \\ Working Paper 19965 \\ http://www.nber.org/papers/w19965
NATIONAL BUREAU OF ECONOMIC RESEARCH
1050 Massachusetts Avenue
Cambridge, MA 02138
March 2014

We thank Navid Sadri and Kevin Chu for excellent research assistance, and Kyle Barron for useful comments. Participants at the 2013 International Transportation Economics Association annual conference also provided valuable comments. We thank the UCLA Ziman Center for Real Estate and the Mineta Transportation Institute at SJSU for valuable support. All errors remain our own. The views expressed herein are those of the authors and do not necessarily reflect the views of the National Bureau of Economic Research.

NBER working papers are circulated for discussion and comment purposes. They have not been peerreviewed or been subject to the review by the NBER Board of Directors that accompanies official NBER publications.

(C) 2014 by Matthew J. Holian and Matthew E. Kahn. All rights reserved. Short sections of text, not to exceed two paragraphs, may be quoted without explicit permission provided that full credit, including (C) notice, is given to the source. 
Household Demand for Low Carbon Public Policies: Evidence from California

Matthew J. Holian and Matthew E. Kahn

NBER Working Paper No. 19965

March 2014

JEL No. Q54,R41

\section{ABSTRACT}

In recent years, Californians have voted on two key pieces of low carbon regulation. The resulting voting patterns provide an opportunity to examine the demand for carbon mitigation efforts. Household voting patterns are found to mirror the voting patterns by the U.S Congress on national carbon legislation. Political liberals and more educated voters favor such regulations while suburbanites tend to oppose such initiatives. Survey responses at the individual level are shown to predict the spatial variation in actual voting patterns and hence convergent validity for results obtained with stated preference data on voting markets.

Matthew J. Holian

San José State University

One Washington Square

San José, California USA, 95192

matthew.holian@sjsu.edu

Matthew E. Kahn

UCLA Institute of the Environment

Department of Economics

Department of Public Policy

Anderson School of Management

UCLA Law School, Box 951496

Los Angeles, CA 90095-1496

and NBER

mkahn@ioe.ucla.edu 


\section{Introduction}

Climate change mitigation represents the ultimate collective action problem as individuals and nations have strong incentives to free ride and wait for others to reduce their carbon emissions. Even nations that have previously shown a willingness to reduce their emissions have retreated from ambitious carbon mitigation targets. In April 2013, the European Parliament rejected tightening their carbon emissions caps. ${ }^{2}$ This governing body worried that tighter caps would further slow Europe’s economic growth.

California has enacted low carbon regulation and invested in public infrastructure seeking to reduce its greenhouse gas emissions. Two recent examples of these efforts are the California Global Warming Solutions Act (AB32) ${ }^{3}$ and the California High Speed Rail (HSR) project. Passed in 2006, AB32 represents one of Governor Arnold Schwarzenegger's major legislative successes. AB32 bundles a suite of policies, including a carbon cap and trade market, as it seeks to reduce the state's greenhouse gas emissions to 20\% below 1990's level by the year 2020 and to $80 \%$ below the 1990 baseline by the year 2050. HSR is a statewide project to build a train that will travel from San Diego to San Francisco and is projected to reduce reliance on air travel and private vehicles for travelling in the state. This is a long run project that requires billions of state and federal dollars.

From a research perspective, a novel feature of both of these ambitious pieces of low carbon policy is that California voters had the opportunity to express their preferences over them. California has long been known as a center of direct democracy (Matsusaka 2005). In fall 2010, California voters rejected Proposition 23 that sought to void the AB32 regulation. This

\footnotetext{
${ }^{2}$ http://www.nytimes.com/2013/04/17/business/global/europe-rejects-carbon-plan.html?partner=rss\&emc=rss

3 This act is often referred to by its legislative name, Assembly Bill 32, or “AB32”.
} 
Proposition garnered $38 \%$ of the total vote in 2010. In 2008, 52.7\% of voters approved of issuing nearly $\$ 10$ billion in bonds to finance the development of a high-speed rail project.

This paper studies voting on these low carbon initiatives using precinct and census block group level data. We also use micro survey data to test hypotheses concerning the support for low carbon policies. We document that stated preferences based on micro data are highly informative about predicting local aggregate voting patterns (Luttmer 2001).

Our central focus is documenting the role that political ideology and economic geography plays in determining voting patterns on low carbon policies. We posit that political liberals are more likely to support such legislation. In addition, we explore the role that suburban living plays in determining voter support. As we discuss below, suburbanites face higher costs for complying with low carbon regulation's requirements and are located physically further from new rail transit infrastructure. These "price effects" should, all else equal, reduce suburban support for such policies.

\section{The Two California Low Carbon Ballot Initiatives}

Proposition 23 sought to place a moratorium on the rollout of California's ambitious climate change mitigation efforts (known as Assembly Bill 32 (AB32)). It was signed into law in 2006 by Governor Schwarzenegger, and is a landmark piece of environmental regulation. Prop 23 would have suspended AB32, until the unemployment rate fell to 5.5\% for one full year. Thus, a vote for Proposition 23 is a vote against California's unilateral efforts to reduce its greenhouse gas emissions.

The Global Warming Solutions Act of 2006, also known as AB32, is a California state law that requires the California Air Resources Board (CARB) to reduce greenhouse gas emissions from all sources throughout the state to 1990 levels by 2020. This represents 
emissions reductions of about $25 \%$ with much more stringent emissions reductions required by the year 2050 (Hanemann 2008). The penalties for missing these targets are not known.

AB32 represents a bundle of several types of regulations and market mechanisms targeting greenhouse gas (GHG) emissions. The largest policy in CARB's toolbox is the cap and trade system, which in 2013 went into effect for electric utilities and large industrial facilities, and in 2015 is scheduled to go into effect for distributors of transportation, natural gas and other fuels. In addition to the cap and trade system, CARB is responsible for overseeing numerous regulations, including a first-in-the-country GHG emissions standards for light duty vehicles, subsequently adopted by other states and the federal government. Other regulations include an aggressive renewable portfolio standard for the electric utilities so that $33 \%$ of the state's power is to be generated by low carbon wind and solar power by the year 2020. ${ }^{4}$ An open debate continues on the likely impact of such regulation on electricity prices. Some industry consulting studies have claimed that these costs are very high. ${ }^{5}$

The second political issue we study is voter support for California's high speed rail. In 2008, voters approved Prop 1A. The Voter Information pamphlet for that election described Prop 1A (the "Safe, reliable high-speed passenger train bond act.”) as:

To provide Californians a safe, convenient, affordable, and reliable alternative to driving and high gas prices; to provide good-paying jobs and improve California's economy while reducing air pollution, global warming greenhouse gases, and our dependence on foreign oil, shall $\$ 9.95$ billion in bonds be issued to establish a clean, efficient high-speed train service linking Southern California, the Sacramento/San Joaquin Valley, and the San Francisco Bay Area, with at least 90 percent of bond funds spent for specific projects, with private and public matching funds required, including, but not limited to, federal funds, funds from revenue bonds, and local funds, and all bond funds subject to independent audits? Fiscal Impact: State costs of $\$ 19.4$ billion, assuming 30 years to pay both principal and interest costs of the bonds. Payments would average about $\$ 647$

\footnotetext{
${ }^{4}$ Information on these and other regulations can be found at California Environmental Protection Agency, "Fact Sheets / FAQs," http://www.arb.ca.gov/cc/facts/facts.htm (Accessed March 10, 2013).

${ }^{5}$ For example see http://suspendab32.org/AB_32_Report071309.pdf.
} 
million per year. When constructed, unknown operation and maintenance costs, probably over $\$ 1$ billion annually; at least partially, and potentially fully, offset by passenger fares. ${ }^{6}$

Figure 1 displays a map of California and shows the HSR's station stops. This figure highlights that this place-based multi-billion dollar investment will have differential effects across California. Previous research has examined how Europe’s high-speed rail has impacted economic activity (Brakman, Garretse and Schramm 2000). Information provided to ballot voters in 2008 stated that the train would reach top speeds of $220 \mathrm{MPH}$ and allow for a travel time from Los Angeles to San Francisco in about 21/2 hours for about $\$ 50$ per person. ${ }^{7}$

High-speed rail is explicitly described as a low carbon form of transportation. The California Air Resources Board subsequently approved a California HSR Authority report that documents the level of greenhouse gas reductions resulting from the bullet train project. ${ }^{8}$

Figures 2 and 3 display the cross-county spatial distribution in the share of voters who voted in favor of each of these initiatives. Recall that a vote in favor of Prop 23 is an "anticarbon vote” (because it would freeze the implementation of AB32). The figures clearly show that coastal California is more pro-transit and pro-environment than the rest of the state, as is the northern portion, at least along the coast.

\footnotetext{
${ }^{6}$ http://voterguide.sos.ca.gov/past/2008/general/ballot-sum/ballot-meas-sum1a.htm

${ }^{7}$ If a voter visited the California HSR Authority webpage before the election, they would have seen a route map on cahighspeedrail.ca.gov that we reviewed (from 10/15/2008, http://web.archive.org/web/20081015154427/http://www.cahighspeedrail.ca.gov/)

This route map is identical in terms of route and stations to our Figure 1. The 2008 map listed the following stations names: San Francisco, SFO Airport, Redwood City/Palo Alto, San Jose, Gilroy, Fresno, Visalia/Tulare/Hanford, Bakersfield, Palmdale, Sylmar, Burbank, Los Angeles. This map also listed the following stations North of Fresno: Sacramento, Stockton, Modesto, Merced, and the following stations south of Los Angeles: Norwalk, Anaheim, Irvine, City of Industry, Ontario Airport, UC Riverside, Murrietta, Escondido, University City, San Diego. For more details about HSR see http://www.almanacnews.com/blogs/p/2013/12/18/the-bullet-train-what-does-it-sayabout-our-state-government.

${ }^{8}$ http://www.arb.ca.gov/cc/scopingplan/sp_measures_implementation_timeline.pdf
} 


\section{The Determinants of Low Carbon Voting}

AB32 represents a bundle of different efforts to reduce every sector's carbon emissions.

One major piece of this effort is the nation's first carbon cap and trade market. This new market will raise the price of both gasoline and electricity.

In comparing the private benefits and costs of supporting a piece of carbon mitigation regulation, it is intuitive that environmentalists will gain greater benefits from enacting such regulation. There is a subset of the population who loses utility from polluting and this creates a personal incentive for these individuals to engage in voluntary restraint even when they face no Pigouvian incentive not to pollute (Kotchen and Moore 2008).

In this section, we present a rational choice model of voting in favor of low carbon legislation. Each person gains utility from private consumption, $c$, housing, $h$, and loses utility from its emissions of carbon. For simplicity, we assume that the population has the same preferences over consumption and housing and that carbon enters the utility function in an additively separable component. The population differs with respect to its disutility from producing pollution. For people who are free riders, $B$ equals zero in equation (1), while a larger $B$ indicates a greater willingness to engage in voluntary restraint. ${ }^{9}$

$$
\operatorname{Max} U(c, h)-B \times \text { carbon }
$$

In addition to differing with respect to $B$, households also differ with respect to their hourly wage, measured in dollars and defined as $W$. In equation (1), carbon is a choice variable that will be a function of household transportation and housing choices. ${ }^{10}$

\footnotetext{
${ }^{9}$ Each household views themselves as small in the market economy and thus aggregate carbon emissions are unaffected by each household's contribution to the total stock of the pollutant. We could augment the utility function to include the aggregate stock of carbon emissions. Those with a larger "B" for private carbon emissions would derive more disutility from the growing aggregate GHG stock.

${ }^{10}$ In our model, we do not explicitly incorporate other features of geography such as summer temperature. In California, areas closer to the water are both more expensive and feature cooler summers. Inland residents will
} 
Each household must commute to the city center by car or by bus. To simplify the problem, we assume that commuters rent access to the bus or car. The car is more expensive and emits more carbon per mile than the bus (because of economies of scale for public transit) but the car is faster. The car's rental price is $r_{\text {car }}$ and the bus's daily rental price (i.e. its fare) is $r_{\text {bus }}$.

In addition to choosing a commuting mode, each household must also choose the distance from the city center at which it lives, and the quantity of housing it will consume. These choices in turn also determine the household's carbon production. The hedonic pricing gradient determines the price of housing at each distance from the city center. Homes closer to the city center will be more expensive (because a shorter commute is a desirable attribute) and at any distance from the city center, the price of a home will be an increasing function of its size. Call this hedonic pricing gradient $P(h, d)$.

With this notation, each household faces the following optimization problem:

$$
\operatorname{Max}_{d, c, h, c a r, b u s} U(c, h)-B \times \text { carbon }
$$

Subject to:

$$
\begin{gathered}
W \times\left(24-\frac{d}{\text { speed }_{\text {car }}}\right)=c+P(h, d)+r_{c a r}+p_{g} \times \frac{d}{M P G_{\text {car }}}, \text { if commute by car } \\
W \times\left(24-\frac{d}{\text { speed }_{\text {bus }}}\right)=c+P(h, d)+r_{\text {bus }}, \text { if commute by bus } \\
\text { carbon }=\alpha_{2} \times \frac{d}{\left(M P G_{\text {bus }} / \text { occupancy }\right)}+f \times h, \text { for bus commuters. } \\
\text { carbon }=\alpha_{1} \times \frac{d}{M P G_{\text {car }}}+f \times h, \text { for car commuters. }
\end{gathered}
$$

Equation (2) presents the budget constraint for a person who chooses to commute by car. The left side of the equation represents the total income this person earns. Note that total income 
is a decreasing function of his commute distance (holding speed of the car constant). His total income is greater if the speed of the car is faster because he has more time to work. This car commuter's expenditure is presented on the right side of the budget constraint where he can buy private consumption, housing and one car rental. This car driver must pay the market price for a gallon of gasoline, $p_{g}$, where the number of gallons required depends on commute distance $d$ and vehicle fuel efficiency (miles per gallon,) $M P G_{c a r}$. Equation (3) presents the budget constraint for the bus rider. Bus riders do not pay for gasoline and the bus speed is slower and the bus ticket is cheaper than renting a car.

Finally, equations (4) and (5) distinguish this model from classic monocentric city models with a transport modal choice (Leroy and Sonstelie 1983, Glaeser, Kahn and Rapapport 2008). These equations represent the carbon production functions for bus commuters and car commuters, respectively. The household's carbon production is an increasing function of his commute's total gasoline consumption and thus is weighted by the carbon emissions factor $\alpha_{1}$ if he commutes by car. If he commutes by bus, we must incorporate that the bus is a club good. In this case we take the total gasoline consumption to move the bus an extra mile and divide by the parameter occupancy, which the household treats as the historical average occupancy of the bus, to calculate each person's share of total bus gasoline consumption. Multiplying this amount by $\alpha_{2}$ yields the amount of carbon generated by the average bus rider, per mile from the city center. Finally, the term $f \times h$ reflects that for any house of size $h$, electricity consumption scales with the size of the home. Those who live in larger suburban homes will consume more electricity. Given that over $80 \%$ of U.S power is generated using coal and natural gas, this will increase carbon emissions. In this case, $f$ represents the local electric utility's carbon emissions 
factor. This term would drop out if the utility generated its power with zero carbon wind and solar. $^{11}$

Solving this maximization problem as a function of $B$ and $W$ yields the following comparative statics. Fixing the wage $W$, a person who has a slightly higher $B$ will live in a smaller house, closer to the city center and be more likely to commute by public transit. Holding $B$ constant, a higher wage household will be more likely to live closer to the city center, in a bigger home, and to commute by car. Households with a very low $B$, and households with moderate wages would be the most likely to locate far from the city center. There, they could enjoy a large home and commute by car to reduce their commute time. Such low B suburban households would lose little direct utility due to the carbon they create.

In this economy, household carbon production will be an increasing function of distance to the city center. Further from the city center, the homes are bigger, the commute is longer, and people are more likely to commute by the high carbon private car mode. To provide a sample of the magnitude of the extra operating costs imposed by AB32, suppose that in the near future that the cap and trade provisions raise the price of gasoline by 50 cents a gallon in California. A center city resident with easy access to public transit will face a lower cost imposed by this regulation than a suburban home owner who drives 15,000 miles per year in an SUV that achieves 20 miles per gallon. Under these assumptions, this suburban household will face a marginal increase in transportation cost of $\$ 375$ per year due to the carbon regulation. This example highlights how locational choice and past durables choices together determine the price of complying with carbon regulation.

\footnotetext{
${ }^{11}$ Note that we are assuming that private consumption generates zero carbon. It would be simple to relax this assumption or we could augment the model to have multiple types of consumption that differ with respect to their carbon content.
} 
In this model, those eager to engage in voluntary restraint choose to live close to the city center and choose a commuting mode (the bus) such that the costs they face from AB32 are lower than those who live in the suburbs in a large home, and who commute by private car. In this sense, personal ideology determines the economic price that voters face for complying with new regulation.

This point distinguishes carbon voting from other pieces of environmental regulation. In past work, Peltzman (1984) and Kahn and Matsusaka (1997) have argued that economic factors (rather than ideology) are the dominant determinant of voting on environmental referenda. For example, Kahn and Matsusaka document that counties featuring a larger share of agricultural interests are more likely to vote against environmental regulation that potentially lowers this sector's profitability.

In the case of carbon voting, a household's locational choice is jointly determined by its ideology and its economics circumstances. As highlighted by our model, the interplay of the parameters $\mathrm{B}$ and $\mathrm{W}$ determine the cost of voting in favor of carbon mitigation. We could further enrich our model by incorporating the fact that households have "locked in" to a set of durables and a residential community where they have formed their social networks and have local knowledge over shopping opportunities. ${ }^{12}$ Those who have chosen the suburbs will recognize that it is more costly for them to comply with low carbon regulation mandates. If homes and cars are durable owned assets, rather than rented assets, then the suburbanites who own fuel inefficient vehicles will suffer an asset loss from the introduction of carbon pricing. Standard reasoning from urban economics predicts increased costs of transportation will be

\footnotetext{
${ }^{12}$ We recognize that our model is static. In a more realistic dynamic model, households would purchase durables such as their home and their car. It is reasonable to assume that AB32's introduction represented a surprise for California's voters who had purchased such durables years before. Future research should study how the expectation of rising energy prices in California affects durables demand relative to durables demand by observationally identical households who live in states that are not expected to enact cap and trade legislation.
} 
capitalized into lower prices for suburban real estate - and higher prices of urban land (Blake 2012, Sexton, Wu and Zilberman 2012).

This model has implications for voting on Proposition 23. Consumers make decisions knowing their own private disutility from polluting, their $B$. It is reasonable to assume that those people with a high $B$ also derive higher private benefits from enacting AB32's goals of reducing California's greenhouse gas emissions and serving as a guinea pig for the rest of the world. This suggests that $B$ is positively correlated with the private benefits of voting for AB32. As we discussed above, all else equal, consumers with a higher $B$ will face a lower cost of voting against Prop 23 because their carbon production is lower as they live closer to the city center in small homes and commute using public transit.

Distance to the city center should also have implications for voting on high-speed rail. Given that the station stops will be in the center cities, those who live downtown will have better access than those who live in suburbs of the metropolitan areas along the route. Our residential sorting model also suggests that those with a taste for voluntary restraint will be more likely to live closer to the city center. Under the assumption that people with a taste for voluntary restraint (i.e a high $B$ in equation (1)), care about reducing California's total stock of GHG emissions, then these same individuals should be more likely to support HSR.

\section{The Empirical Framework}

To study the determinants of support for low carbon legislation in California, we study two types of data. The first will be household level surveys of support for the two propositions 
and the second set will be actual voting at the census block group level. Following the earlier literature on environmental voting, we will include standard demographic controls such as age, ethnicity, education and income. ${ }^{13}$ In terms of the socioeconomic variables, we expected that more educated, richer voters will support carbon mitigation.

We are especially interested in the role of political ideology in the household or in the neighborhood where the household lives, and the role of urban form where urban form will be measured by distance to the center city and the population density in the household's local geographic area.

In studying California voter behavior, when using survey data we estimate the following model:

$$
\text { Vote Yes }{ }_{i j}=\beta_{c j}+w_{i}^{\prime} \beta_{1 j}+\beta_{2 j} x_{i}+v_{i}^{\prime} \beta_{3 j}+\varepsilon_{i j}
$$

Where Vote $Y e s_{i j}$ is a zero or one variable indicating whether or not the respondent $i$ supports proposition $j$. When using aggregate data we estimate the following model:

$$
\text { Percent } \text { Yes }_{i j}=\beta_{c j}+w_{i}^{\prime} \beta_{1 j}+\beta_{2 j} x_{i}+v_{i}^{\prime} \beta_{3 j}+\varepsilon_{i j}
$$

where Percent $Y e s_{i j}$ refers to the percent of precinct $i$ voting yes on a proposition $j$. We include county $(c)$ fixed effects in each regression, $\beta_{c j}$. Three types of explanatory variables are defined by the vectors $w, x$ and $v$ : In equation (7), $w_{i}$ is a vector and represents socioeconomic and demographic variables in precinct $i$ and $\beta_{1 j}$ is the coefficient vector on these terms, $x_{i}$ is a scalar and represents an ideological variable in precinct $i$ and $\beta_{2 j}$ is the coefficient on this variable, and $v_{i}$ is a vector of urban form variables for precinct $i$ and $\beta_{3 j}$ is

\footnotetext{
${ }^{13}$ This literature includes Deacon and Shapiro (1975), Kahn and Matsusaka (1997), Kahn (2002), Wu and Cutter (2011).
} 
the coefficient vector on these terms. We will estimate equation (7) using ordinary least squares (OLS), while weighting the observations by the total number of votes in precinct $i$ to mitigate heteroskedasticity concerns. ${ }^{14}$ For conceptual clarity, we use the same notation on the right-hand side of equations (6) and (7). This is a slight abuse of notation as the measures in the $w, x$ and $v$ vectors, though capturing identical concepts, are made of up variables taken from survey responses in equation (6), whereas the measures in equation (7) are block group level aggregates. The urban form variables are meant to capture the forces we discussed in the previous section's model. All else equal, we predict that households who live closer to a metropolitan area’s city center will be more likely to vote against Prop 23. In previous research, we have documented that households who live closer to the city center drive less (Holian and Kahn 2014). Suburban residents also spend more on electricity than observationally identical center city residents (see Glaeser and Kahn 2010).

In the economic model presented earlier, we simultaneously modeled the choice of residential location, commute mode and housing demand. All else equal, high "B” households will choose to live closer to the city center and will configure their lives to have a minimal environmental externality impact. Such households will face a low cost of voting for low carbon regulation. This "B" parameter is known by the households but cannot be observed by the econometrician. One way to proxy for this is to use political party registration data. We are implicitly assuming that Democrats have a high “B”. Costa and Kahn (2013) document that political liberals consume less electricity than observationally identical households and consume

\footnotetext{
${ }^{14}$ Technically, the unit of analysis in our study of the voting data is the block group. We merge voting data to block groups. However, it is less intuitive to describe "the percent of the block group voting for X", because most readers know that in the U.S. voting takes place in precincts whose boundaries rarely coincide perfectly with block groups.
} 
even less on hot summer months. Kahn (2007) document that political liberals are more likely to own hybrid vehicles and to install solar panels.

Figure 4 documents where Democrats and Republicans live within California’s metropolitan areas. More than 50\% of residents who live within five miles of a city center are Democrats. This share shrinks monotonically with distance from the city center. In contrast, roughly $25 \%$ of residents who live within five miles of a city center are Republicans and this share rises monotonically with distance from the city center. Note the fractions of Democrats and Republicans do not sum to one in the figure as there are a number of independent voters and those who register within one of several minor parties.

Our reduced form estimates of the voting propensities represents a conditional analysis. Given where households have chosen to live, we study their voting patterns. We acknowledge that we do not explicitly model the residential locational choice decision. ${ }^{15}$ In the absence of random assignment of households to different distances from the city center, we cannot recover the causal effect of suburbanization on opposing low carbon policy efforts.

While we acknowledge this point, it is important to note that households also choose their locations based on many idiosyncratic factors that are unlikely to be correlated with their propensities to vote on environmental legislation. People differ with respect to their place of work with some working downtown and others working in the suburbs (Glaeser and Kahn 2001). People differ with respect to whether they have school-aged children and whether they are willing to use the center city public schools. Some households may have a strong taste for the downtown culture and retail opportunities and the city center’s consumer city (Glaeser, Kolko and Saiz 2001). Households may seek to live near a family member who can help with babysitting or near an elderly parent who requires their assistance. These examples highlight

\footnotetext{
${ }^{15}$ We know of no empirical studies that jointly examine where households choose to live and how they vote.
} 
that households are sorting within metropolitan areas for many reasons that may be independent of the unobserved determinants of voting on low carbon legislation. We must rely on the fact that we have included a detailed set of explanatory variables in our attempt to isolate the association between geographic location and support for low carbon policies.

\section{Data}

We obtained our data from a variety of sources. The Statewide Database (SWDB) at UC Berkeley distributes statement of vote files matched to Census blocks for elections between 1992 and present. The two survey data sets we analyze were both collected by the Public Policy Institute of California (PPIC).

For our analysis of voting data, we merge additional variables to the data supplied by SWDB, namely the 2006-2010 American Community Survey (ACS) Five-Year Estimates (which replaced the decennial Census as the primary source for important socioeconomic variables, including income and education at the block-group level.)

The survey data was collected in July 2010 and in March of 2012. The 2010 survey asked about opinions towards global warming in general and AB32 in particular, although it did not specifically name Proposition 23. One important characteristic of this survey for our purposes is the availability of zip code identifiers for respondents, thus allowing us to calculate measures of distance from zip code centroids to downtown, as well as neighborhood population density. ${ }^{16}$ The 2010 PPIC survey also asked the following question,

Next, to address global warming, do you favor or oppose the state law that requires

\footnotetext{
${ }^{16}$ Though not as refined as our measure of these variables calculated using block group centroids in the voting data.
} 
California to reduce its greenhouse gas emissions back to 1990 levels by the year 2020? While the 2012 PPIC survey asked:

Do you favor or oppose building a high-speed rail system in California? (favor, oppose) We coded "favor" answers to these questions as one, "oppose" answers as zero, and we dropped the few dozen respondents who either refused to answer or were unsure.

To proxy for environmental ideology, we include voting indicators. To study voting on both propositions, we use the fraction of the block group voting for George Bush in the 2004 election as a control for ideology. Snyder (1996) documents that political party registration data is an important correlate of voting on California referenda. For the survey data, we drop all unregistered voters, and generate an indicator variable equal to one if the respondent is a registered Republican.

The variable lnDISTANCE was created by merging geocodes to the ACS block group and the PPIC zip code level data, and then using the 2006 definitions of metropolitan areas, we calculated the distance from each block group to the center of the MSA in which the block group or zip code is in. For block groups and zip codes that are not in an MSA, we set their distance equal to 80 kilometers, which is the location we have arbitrarily chosen as the urban fringe. Given the presence of some zero and very low distances and densities, we take the natural log of one plus the distance in kilometers. Similarly, the lnDENSITY variable is the natural log of one plus population density at the block group level, measured as population by land area, measured in square miles.

Our study's variable definitions and summary statistics are reported in Tables 1 through 4. Comparing the variable descriptions in Tables 1 and 2 clarifies the differences between the component variables of the $w, x$ and $v$ vectors in equations (6) and (7). For example, $\operatorname{lnINC}$ is 
the natural log of (one plus) block group average household income in the aggregate data, and the natural log of (one plus) the respondent's self-reported income in the survey data. Tables 3 and 4 provide summary statistics for the three datasets. Across the two surveys most averages are quite similar; one exception is that the average value of BLACK was 19\% in the 2010 survey but $7 \%$ in the 2012 survey. In comparison, the average value of BLACK was $6 \%$ in the aggregate data. As a general statement, the survey data appear to slightly oversample older, richer, more educated and more liberal voters.

\section{Results}

Table 5 reports four regressions to investigate the correlates of support for AB32. The first two columns report estimates of equation (7) using the block group level data while the last two columns report estimates of equation (6) using the survey data. It is important to note that in columns (1) and (2) the dependent variable is the share of the block group who voted "no" on Prop 23 so this is indicative of support for AB32. We transform the dependent variable so we can directly compare the precinct level regressions with the survey regressions. County fixed effects are included in each regression.

Table 5 highlights the similarities and the differences in the results between the precinct regressions and the survey regressions. To streamline this discussion, we focus on the results reported in columns (2) and (4) where we include the political variables. Across the specifications, we consistently find that Republicans oppose AB32. A ten percentage point increase in the share of registered Republicans reduces the probability of voting "No" on Prop 23 by 5.5 percentage points. To compare with the survey data, we consider a 100 percentage point increase, which reduces the probability of voting no on Prop 23 by 55 percentage points. This 
compares with the 37 percentage point reduction associated with the results from the survey data in column (4). Both results suggest ideology has a very large effect on support for carbon mitigation regulation.

A second finding is that those who live at higher population density and closer to the city center are more likely to favor AB32. While the urban form variables are statistically significant and of the expected signs, they do not explain as much as ideology. ${ }^{17}$

One new finding is that controlling for education, richer people are not more likely to support AB32. The standard J-curve logic is that richer people and nations are more likely to support environmental regulation. The income effect's magnitude shrinks when we control for the community’s political party voting. As shown in Tables 5 and 6, both homeowners and homeowner communities consistently vote against low carbon regulation.

Several of the demographic variables do not yield similar findings in the survey micro regressions and the precinct level regressions. While more educated people support AB32, this variable is statistically insignificant in the survey regressions. Relatively few demographic variables are statistically significant in the survey regressions. ${ }^{18}$

\footnotetext{
${ }^{17}$ In unreported results, we estimated restricted models with county fixed effects and ideology only, and also models with urban form and fixed effects only, and the R-squared in the former restricted model is much higher. As a robustness check, we also estimated a specification using the voting data that included the fraction of voters registered with the Green Party. The coefficient on this variable had the theoretically expected sign, was statistically significant, and was larger in magnitude in the Prop 23 model than the Prop 1A model. The R-squared increased only very slightly when we included this additional measure of ideology, and the coefficients on the other variables, specifically the urban form variables (lnDISTANCE and lnDENSITY) also changed only very slightly. These results are available upon request.

${ }^{18}$ We carried out several joint F-tests. We reject the hypothesis that the coefficients on all of the demographic variables are jointly zero $(\mathrm{p}<0.01)$, and we reject the hypothesis that the coefficients on the race and ethnicity variables are jointly zero $(\mathrm{p}<0.01)$. However, we do not reject the hypothesis that InINC and COLLEGE are jointly zero $(\mathrm{p}<0.14)$ in the survey data results for AB32.
} 
Table 6 reports the high-speed rail results. Richer people oppose it while more educated people support it. Similar to the voting on AB32, people who live further from the city at lower population density oppose it and Republicans are less likely to support it.

Homeownership is found to reduce support for HSR on average. At first glance, this is a surprising result. In the case of high-speed rail, voters should recognize that there will be a direct real estate capitalization effect for those who live closer to the planned station stops. Recent evidence from China's bullet trains (see Zheng and Kahn 2013) documents positive capitalization effect of distance to the rail stop.

HSR represents a complex treatment because of its implications for existing land use patterns. In the major cities, suburban NIMBY's and in agricultural areas, farmers, have used their voice to vote against Prop $1 \mathrm{~A}$ and also to challenge its legality. At the same time, a majority of voters did support Prop 1A in Central Valley areas like Bakersfield and Fresno, which are historically conservative areas but which will effectively become suburbs of Los Angeles and San Francisco once HSR is built. However Prop 1A did not receive the support of a majority of voters, even in some Central Valley communities where the train will stop. ${ }^{19}$

Fischel (2001) describes the powerful incentives faced by homeowners to vote, and more generally behave, in ways consistent with improving but especially preserving the value of their homes. $^{20}$

\footnotetext{
${ }^{19}$ In Fresno, Kern, Merced and San Joaquin a majority of voters approved Prop 1A, while in Stanislaus, Sacramento, Kings, Madera and Tulare a minority approved. The three largest city in these counties are Fresno $(461,116)$, Sacramento (456,441 ) and Bakersfield (295,536, which is in Kern County.) Population as of 2005. For an overview of these issues see: http://www.usatoday.com/story/news/nation/2013/10/20/calif-high-speedrail/3090811/

${ }^{20}$ We visited Fresno in spring of 2013 and attended a realtor conference. One of the speakers, a realtor specializing in agricultural land, provided anecdotal evidence that agricultural land values in the area were indeed on the rise, and moreover that out of town buyers from places like San Francisco were increasingly involved in transactions. Although he attributed this to a rise in almond prices rather than speculation fueled by HSR, this is suggestive and future research should disentangle these various effects of HSR on property values.
} 


\section{Self Reported Low Carbon Preferences and Aggregate Voting Outcomes}

In this section, we follow Luttmer (2001) and use the survey regression results to test whether the marginal effects generated from survey data are informative in predicting aggregate voting outcomes. We use the results from equation (6) and take the regression coefficient vector and multiply this by community level demographics and predict each census tract's average likelihood of supporting low carbon regulation. We then correlate this predicted index with the actual aggregate voting data. If the survey results are truthfully reported then the regression estimates should have some predictive power of actual voting behavior. Table 7 reports the results. We find a strong positive correlation between these two measures of preferences for low carbon regulation.

The scatterplot presented in Figure 5 shows the actual block group vote share on the yaxis and the predicted vote share (calculated without fixed effects, given our survey sample did not contain respondent data from the majority of counties) on the x-axis. In his study of welfare preferences, Luttmer found the adjusted R-squared in this simple regression to be 0.407 . Fitting a straight line to the points in our scatter plot, the adjusted R-squared is 0.685 .

\section{Discussion}

In recent years, more and more people are living further from city centers. Table 8 presents data for the U.S metropolitan population for each decade from 1970 to 2010 on the share of residents who live within different distance bands of the city center. In each row, the entries sum to one. In 1970, 31.6\% of the metropolitan population lived within five miles of the city center while by the year 2010, this percentage had shrunk to $16.9 \%$. In 1970, the share living within ten miles of the city center was $57.2 \%$ and this had shrunk to $35.7 \%$ by 2010 . In 
Tables 5 and 6, we documented a negative correlation between living further from the city center and favoring low carbon policies. If this correlation represents a causal effect, then this suburbanization trend has implications for the political economy of low carbon voting.

The link between suburbanization and carbon production, as highlighted by our model, can be attenuated by the introduction of more fuel-efficient vehicles and electricity generated by zero carbon renewable power. If these products exist, then a suburbanite’s GHG emissions would be roughly equal to his center city counterpart. In this case, the cost of voting for low carbon regulation would fall significantly for suburbanites.

\section{Conclusion}

In recent years, California's voters have had the opportunity to repeal the low carbon AB32 regulation and to choose whether to go forward with investing in costly High-Speed Rail. In both cases, the voters chose the low carbon choice but there was significant spatial variation in the support for these measures. Controlling for standard demographics such as ethnicity, education and income, we have focused on the role of political affiliation and geography as correlates of low carbon voting. We find that political liberals consistently support low carbon initiatives.

All else equal, those who live further from the city center are more likely to oppose low carbon policies. The U.S is a suburban nation with the median metropolitan area resident living 9.9 miles from the city center and $25 \%$ of the population living at least 17.1 miles away from the city center in the year 2000. Relative to nations with more urbanized populations, people in the U.S drive more, live in larger homes and consume more electricity. This fossil fuel driven lifestyle raises the short run price of voting in favor of carbon mitigation regulation. 
Our findings mirror nationwide findings concerning the correlates of Congressional voting on low carbon legislation such as the 2009 American Clean Energy and Security Act concludes that Representatives whose districts are rich, liberal and low carbon are much more likely to vote in favor of carbon mitigation (Cragg et. al. 2013).

Together these results highlight that even within a well known "Blue State" such as California that there is both an ideological divide and a city versus suburb divide on carbon mitigation policy efforts. While economists have stressed the insurance benefits from avoiding “known unknown” fat tail risks (Weitzman 2009, Pindyck 2011), subsets of voters are rejecting this vision.

Past political economy studies have stressed that voters will oppose environmental regulations that threaten their jobs (Kahn and Matsusaka 1997). This paper has presented new evidence on the role that residential lifestyle choices and ideology play in determining low carbon voting patterns. Given existing technologies, our results suggest that the suburbanization of the median voter poses a challenge for policy makers who seek to have the United States lead in international efforts to sign a global carbon treaty.

\section{References}

Blake, Thomas. "What's Exile to the Exurbs Worth? Commuting Costs and Geographic Sorting in the Housing Market." Working Paper, 2012.

Brakman , Steven, Harry Garretsen , and Marc Schramm . "The Empirical Relevance of the New Economic Geography: Testing for a Spatial Wage Structure in Germany." CESifo Working Paper Series No. 395, 2000. http://www.cesifogroup.de/portal/pls/portal/docs/1/1190850.pdf (Accessed March 10, 2013).

California Environmental Protection Agency. "Assembly Bill 32: Global Warming Solutions Act.” http://www.arb.ca.gov/cc/ab32/ab32.htm (Accessed March 10, 2013). 
California Environmental Protection Agency. "Fact Sheets / FAQs."

http://www.arb.ca.gov/cc/facts/facts.htm (Accessed March 10, 2013).

California Environmental Protection Agency. “Trends in California Greenhouse Gas Emissions for 2000 to 2009.” http://www.arb.ca.gov/cc/inventory/pubs/reports/ghg_inventory_0009_trends.pdf (Accessed March 10, 2013).

California High-Speed Rail Authority. “California High-Speed Rail Program Revised 2012 Business Plan.” April 2012. http://www.cahighspeedrail.ca.gov/WorkArea/DownloadAsset.aspx?id=12242. (Accessed March 10, 2013).

California High-Speed Rail Authority. “Interactive Map.” http://www.cahighspeedrail.ca.gov/trip_planner.aspx (Accessed March 10, 2013).

California High-Speed Rail Authority. "Starting in the Central Valley." http://www.cahighspeedrail.ca.gov/centralvalleystart.aspx (Accessed March 10, 2013).

California Official Voter Information Guide. "Ballot Measures Defined.” http://vote2002.sos.ca.gov/2002-vig/default_sid=4\&id=108.asp (Accessed March 10, 2013).

California Voter Foundation. “\#181 Passenger Rail And Clean Air Bond Act of 1994.” http://www.calvoter.org/archive/94general/props/181.html (Accessed March 10, 2013).

Costa, Dora L., and Matthew E. Kahn. "Do liberal home owners consume less electricity? A test of the voluntary restraint hypothesis." Economics Letters(2013).

Cragg, Michael I., Yuyu Zhou, Kevin Gurney, and Matthew E. Kahn. "Carbon Geography: The Political Economy of Congressional Support For Legislation Intended to Mitigate Greenhouse Gas Production." Economic Inuiry 51 (2013): 1640-1650.

Deacon, Robert T. and Perry Shapiro. "Private Preference for Collective Goods Revealed Through Voting on Referenda." The American Economic Review 65 (1975): 943-955.

Fischel, William A. The Homevoter Hypothesis: How Home Values Influence Local Government Taxation, School Finance, and Land-Use Policies. Cambridge, Mass.: Harvard University Press, 2001.

Glaeser, Edward L., and Matthew E. Kahn. Decentralized employment and the transformation of the American city. No. w8117. National Bureau of Economic Research, 2001.

Glaeser, Edward L., and Matthew E. Kahn. "The Greenness of Cities: Carbon Dioxide Emissions and Urban Development." Journal of Urban Economics 67 (2010): 404-418. 
Glaeser, Edward L., Matthew E. Kahn, and Jordan Rappaport. "Why do the poor live in cities? The role of public transportation." Journal of Urban Economics 63, no. 1 (2008): 1-24.

Glaeser, Edward L., Jed Kolko, and Albert Saiz. "Consumer city." Journal of economic geography 1, no. 1 (2001): 27-50.

Hanemann, Michael. "California's new greenhouse gas laws." Review of Environmental Economics and Policy 2, no. 1 (2008): 114-129.

Hårsman, Björn and John M. Quigley. "Political and Public Acceptability of Congestion Pricing: Ideology and Self-Interest." Journal of Policy Analysis and Management 29 (2010): 854874.

Holian, Matthew J., and Matthew E. Kahn. "The Rise of the Low Carbon Consumer City." NBER Working Paper No. w18735, 2013.

Institute of Governmental Studies. "California Ballot Measure Guides.” http://igs.berkeley.edu/library/california-ballot-measure-guides (Accessed March 10, 2013).

Kahn, Matthew E. "Do greens drive Hummers or hybrids? Environmental ideology." Journal of Environmental Economics and Management as a determinant of consumer choice 57 (2007): 129-145.

Kahn, Matthew E. "Demographic Change and the Demand for Environmental Regulation." Journal of Policy Analysis and Management 21 (2002): 45-62.

Kahn, Matthew E. and John G. Matsusaka. "Demand for Environmental Goods: Evidence from Voting Patterns on California Initiatives." Journal of Law and Economics 40 (1997): 137174.

Kotchen, Matthew J., and Michael R. Moore. "Conservation: From voluntary restraint to a voluntary price premium." Environmental and Resource Economics 40, no. 2 (2008): 195-215.

LeRoy, Stephen F., and Jon Sonstelie. "Paradise lost and regained: Transportation innovation, income, and residential location." Journal of Urban Economics 13, no. 1 (1983): 67-89.

Luttmer, Erzo F. P. "Group Loyalty and the Taste for Redistribution." Journal of Political Economy 109 (2001): 500-528.

Matsusaka, John G. "Direct democracy works." Journal of Economic Perspectives (2005): 185206.

Peltzman, Sam. "Constituent interest and congressional voting." Journal of Law \& Economics. 27 (1984): 181. 
Pindyck, Robert S. "Fat tails, thin tails, and climate change policy." Review of Environmental Economics and Policy 5, no. 2 (2011): 258-274.

Sexton, Steven E., JunJie Wu, and David Zilberman. "How High Gas Prices Triggered the Housing Crisis: Theory and Empirical Evidence." (2012).

Snyder, Jr., James M. "Constituency Preferences: California Ballot Propositions, 1974-90." Legislative Studies Quarterly 21 (1996): 463-488.

U.S. Census Bureau. “2010 Census TIGER/Line® Shapefiles.” http://www.census.gov/geo/www/tiger/tgrshp2010/tgrshp2010.html (Accessed March 10, 2013).

U.S. Census Bureau. “Census Block Relationship Files.” http://www.census.gov/geo/www/relate/rel_blk.html (Accessed March 10, 2013).

Weitzman, Martin L. "On modeling and interpreting the economics of catastrophic climate change." The Review of Economics and Statistics 91, no. 1 (2009): 1-19.

Wu, Xiaoyu and Bowman Cutter. "Who votes for public environmental goods in California? Evidence from a spatial analysis of voting for environmental ballot measures." Ecological Economics 70 (2011): 554-563.

Zheng, Siqi, and Matthew E. Kahn. "China’s bullet trains facilitate market integration and mitigate the cost of megacity growth." Proceedings of the National Academy of Sciences 110, no. 14 (2013): E1248-E1253. 
Figure 1: California High Speed Rail (HSR) Map

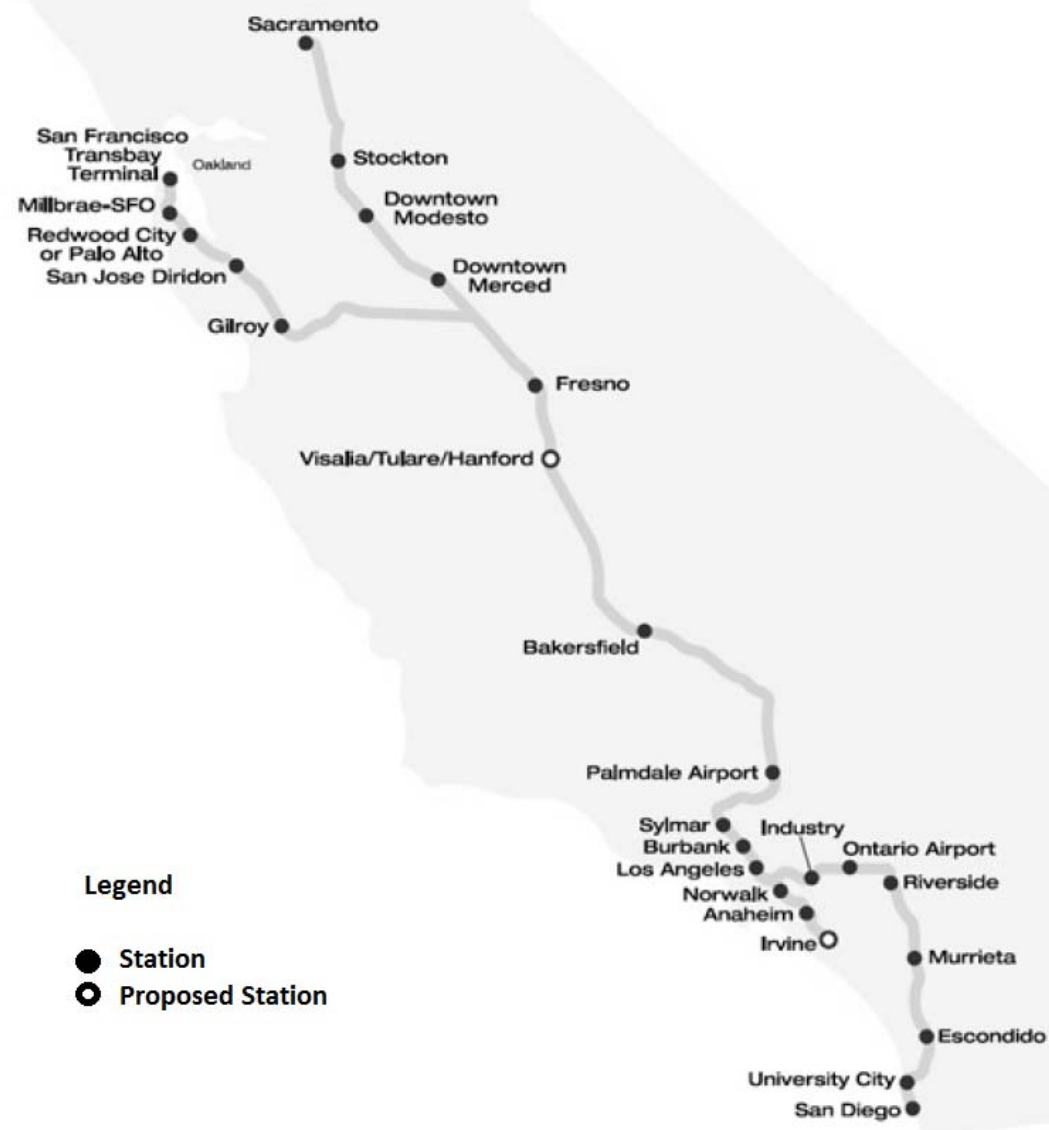

Source: Modified version of map appearing on page 7 of the California High-Speed Rail Authority's November 2008 Business Plan 
Figure 2: Percent of County Voting Yes on Prop 23

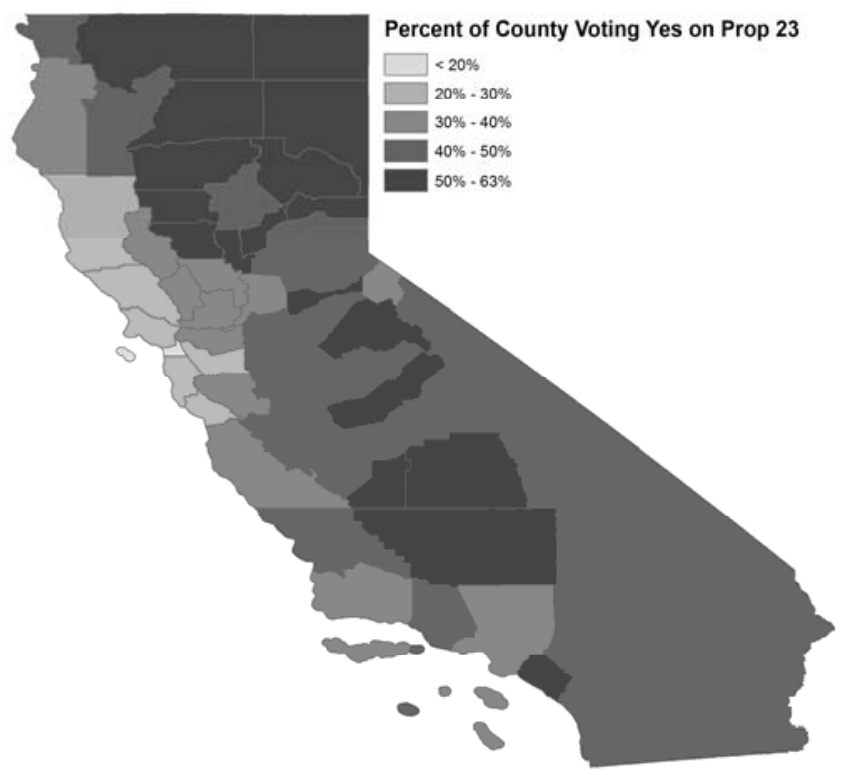

Figure 3: Percent of County Voting Yes on Prop 1A

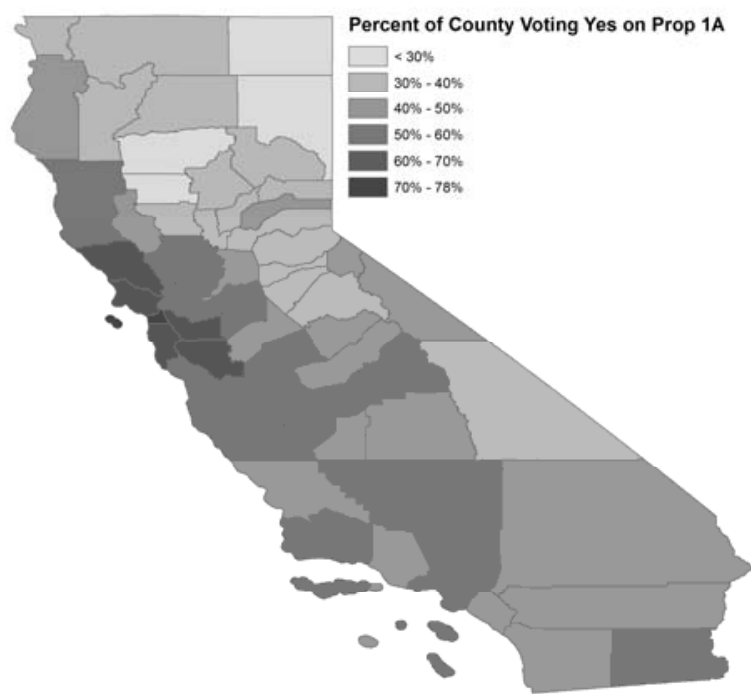


Figure 4: Political party Membership and Distance from the City Center

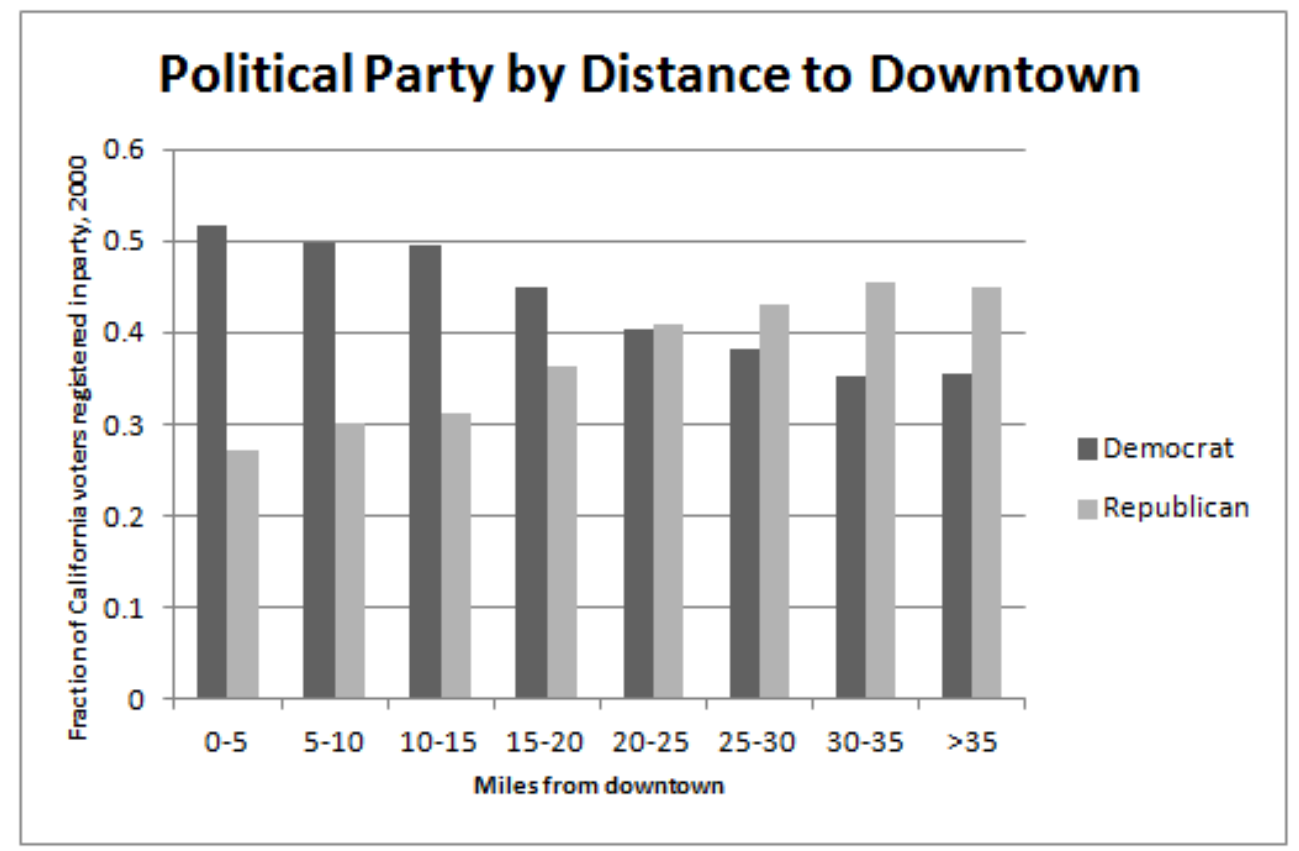

Figure 5: Actual versus Predicted Block-Group Vote Shares, Prop 23

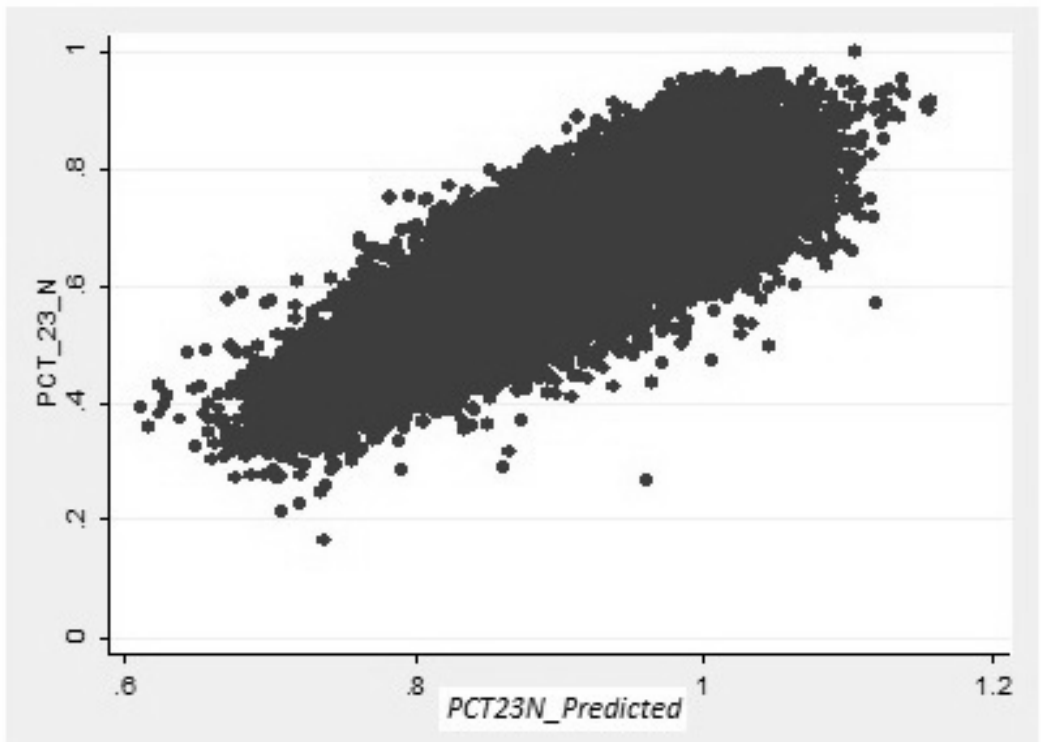


Table 1: Variable Descriptions, Census and Voting Data

\begin{tabular}{ll}
\hline Variable & Description \\
\hline PCT_1A_Y & percent of block group voting yes on Prop 1A \\
PCT_23_N & percent of block group voting no on Prop 23 \\
lnINC & natural log of average household income \\
COLLEGE & percent of block group with college degree or higher \\
BLACK & percent of block group black \\
ASIAN & percent of block group Asian \\
OTHER & percent of block group in "other" race category \\
HISP & percent of block group Hispanic \\
YOUNG & percent of adult population between 18 and 34 \\
OLD & percent of adult population above 65 \\
BUSH & percent of block group voting for Bush in 2004 \\
HOMEOWN & percent of block group that are homeowners \\
lnDISTANCE & natural log of one plus distance to center of MSA \\
lnDENSITY & natural log of one plus density of block group \\
\hline
\end{tabular}

Table 2: Variable Descriptions, Survey Data

\begin{tabular}{|c|c|}
\hline Variable & Description \\
\hline SUPPORT_AB32 & respondent favors AB32 \\
\hline SUPPORT_HSR & respondent favors building a HSR system in California \\
\hline $\operatorname{lnINC}$ & natural logarithm of income \\
\hline COLLEGE & educational attainment; College degree or higher \\
\hline BLACK & black \\
\hline ASIAN & Asian \\
\hline OTHER & answered "other" to race and ethnicity question \\
\hline HISPANIC & Hispanic \\
\hline YOUNG & age between eighteen and thirty-four \\
\hline OLD & age 65 or greater \\
\hline REP & respondent is a registered Republican \\
\hline HOMEOWNER & respondent owns their home \\
\hline $\operatorname{lnDISTANCE}$ & natural logarithm of distance to center of MSA $(\mathrm{km})$ \\
\hline $\operatorname{lnDENSITY}$ & natural log of density (population / square mile) \\
\hline
\end{tabular}


Table 3 : Summary Statistics, Census and Voting Data

\begin{tabular}{lccrrrr} 
Variable & Obs & Mean & Std. Dev. & Min & Max \\
\hline PCT_1A_Y & 23,134 & 0.54 & 0.12 & 0 & 1 \\
PCT_23_N & 23,126 & 0.63 & 0.12 & 0 & 1 \\
lnINC & 23,048 & 4.31 & 0.48 & 1.31 & 6.53 \\
COLLEGE & 23,118 & 0.30 & 0.21 & 0 & 1 \\
BLACK & 23,123 & 0.06 & 0.12 & 0 & 1 \\
ASIAN & 23,123 & 0.12 & 0.16 & 0 & 1 \\
OTHER & 23,123 & 0.19 & 0.16 & 0 & 1 \\
HISP & 23,123 & 0.34 & 0.28 & 0 & 1 \\
YOUNG & 23,123 & 0.32 & 0.14 & 0 & 1 \\
OLD & 23,123 & 0.16 & 0.11 & 0 & 1 \\
REP & 23,110 & 0.41 & 0.19 & 0 & 1 \\
HOMEOWN & 23,082 & 0.59 & 0.28 & 0 & 1 \\
lnDISTANCE & 23,211 & 3.00 & 0.88 & 0.02 & 4.39 \\
lnDENSITY & 23,189 & 8.38 & 1.70 & 0.00 & 12.33 \\
\hline
\end{tabular}

Table 4 : Summary Statistics, Survey Data

Environmental Survey

High-Speed Rail Survey

\begin{tabular}{lllllllllll}
\hline Variable & Obs & Mean & Std. Dev. & Min & Max & Obs & Mean & Std. Dev. & Min & Max \\
\hline SUPPORT_AB32 & 2509 & 0.73 & 0.44 & 0 & 1 & & & & & \\
SUPPORT_HSR & & & & & & 2196 & 0.49 & 0.50 & 0 & 1 \\
lnINC & 2627 & 10.99 & 0.75 & 9.90 & 12.21 & 2096 & 10.93 & 0.76 & 9.90 & 12.21 \\
COLLEGE & 2840 & 0.46 & 0.50 & 0 & 1 & 2320 & 0.40 & 0.49 & 0 & 1 \\
BLACK & 2840 & 0.19 & 0.39 & 0 & 1 & 2320 & 0.07 & 0.25 & 0 & 1 \\
ASIAN & 2840 & 0.07 & 0.26 & 0 & 1 & 2320 & 0.08 & 0.27 & 0 & 1 \\
OTHER & 2840 & 0.19 & 0.39 & 0 & 1 & 2320 & 0.21 & 0.41 & 0 & 1 \\
HISPANIC & 2840 & 0.27 & 0.45 & 0 & 1 & 2320 & 0.22 & 0.42 & 0 & 1 \\
YOUNG & 2840 & 0.23 & 0.42 & 0 & 1 & 2247 & 0.21 & 0.41 & 0 & 1 \\
OLD & 2840 & 0.21 & 0.41 & 0 & 1 & 2247 & 0.23 & 0.42 & 0 & 1 \\
HOMEOWNER & 2707 & 0.67 & 0.47 & 0 & 1 & 2320 & 0.63 & 0.48 & 0 & 1 \\
lnDISTANCE & 2636 & 3.06 & 0.90 & -2.25 & 4.38 & & & & & \\
lnDENSITY & 2698 & 7.76 & 1.63 & 1.39 & 10.89 & & & & & \\
REP & 2840 & 0.30 & 0.46 & 0 & 1 & 2320 & 0.29 & 0.45 & 0 & 1 \\
\hline
\end{tabular}

Note: Reported observations reflect weighting 
Table 5: Voting and Survey Regressions on Support for AB32

\begin{tabular}{|c|c|c|c|c|}
\hline VARIABLES & PCT_23_N & PCT_23_N & support_AB32 & support_AB32 \\
\hline $\operatorname{lnINC}$ & $\begin{array}{l}-0.0529 * * * \\
(0.0018)\end{array}$ & $\begin{array}{l}-0.00491 * * * \\
(0.0011)\end{array}$ & $\begin{array}{l}-0.0736^{* * *} \\
(0.0164)\end{array}$ & $\begin{array}{l}-0.0308 * * \\
(0.0154)\end{array}$ \\
\hline COLLEGE & $\begin{array}{l}0.250 * * * \\
(0.0037)\end{array}$ & $\begin{array}{l}0.0998 * * * \\
(0.0023)\end{array}$ & $\begin{array}{l}0.0788 \\
(0.4360)\end{array}$ & $\begin{array}{l}0.0374 \\
(0.4050)\end{array}$ \\
\hline BLACK & $\begin{array}{l}0.154^{* * *} \\
(0.0043)\end{array}$ & $\begin{array}{l}-0.0561 * * * \\
(0.0027)\end{array}$ & $\begin{array}{l}0.074 \\
(0.4370)\end{array}$ & $\begin{array}{l}0.0584 \\
(0.4060)\end{array}$ \\
\hline ASIAN & $\begin{array}{l}-0.0392 * * * \\
(0.0031)\end{array}$ & $\begin{array}{l}-0.0342^{* * *} \\
(0.0018)\end{array}$ & $\begin{array}{l}0.165 \\
(0.4380)\end{array}$ & $\begin{array}{l}0.0915 \\
(0.4070)\end{array}$ \\
\hline OTHER & $\begin{array}{l}0.00705 \\
(0.0048)\end{array}$ & $\begin{array}{l}-0.0044 \\
(0.0028)\end{array}$ & $\begin{array}{l}0.0648 * * \\
(0.0285)\end{array}$ & $\begin{array}{l}0.0394 \\
(0.0265)\end{array}$ \\
\hline HISP & $\begin{array}{l}0.102 * * * \\
(0.0034)\end{array}$ & $\begin{array}{l}-0.0188^{* * *} \\
(0.0021)\end{array}$ & $\begin{array}{l}0.0127 \\
(0.4370)\end{array}$ & $\begin{array}{l}-0.0201 \\
(0.4060)\end{array}$ \\
\hline YOUNG & $\begin{array}{l}0.00608 \\
(0.0048)\end{array}$ & $\begin{array}{l}0.00522 * \\
(0.0028)\end{array}$ & $\begin{array}{l}0.106 * * * \\
(0.0258)\end{array}$ & $\begin{array}{l}0.0761 * * * \\
(0.0240)\end{array}$ \\
\hline OLD & $\begin{array}{l}0.0467 * * * \\
(0.0047)\end{array}$ & $\begin{array}{l}0.0300 * * * \\
(0.0027)\end{array}$ & $\begin{array}{l}-0.0679 * * * \\
(0.0262)\end{array}$ & $\begin{array}{l}-0.0172 \\
(0.0245)\end{array}$ \\
\hline HOMEOWN & $\begin{array}{l}-0.0473^{* * *} \\
(0.0025)\end{array}$ & $\begin{array}{l}-0.00372 * * \\
(0.0015)\end{array}$ & $\begin{array}{l}-0.00588 \\
(0.0242)\end{array}$ & $\begin{array}{l}-0.01 \\
(0.0225)\end{array}$ \\
\hline lnDISTANCE & $\begin{array}{l}-0.0383^{* * *} \\
(0.0007)\end{array}$ & $\begin{array}{l}-0.00935^{* * *} \\
(0.0004)\end{array}$ & $\begin{array}{l}0.00307 \\
(0.0149)\end{array}$ & $\begin{array}{l}0.014 \\
(0.0138)\end{array}$ \\
\hline lnDENSITY & $\begin{array}{l}0.00982^{* * *} \\
(0.0004)\end{array}$ & $\begin{array}{l}0.00570 * * * \\
(0.0002)\end{array}$ & $\begin{array}{l}0.0188 * * \\
(0.0092)\end{array}$ & $\begin{array}{l}0.00874 \\
(0.0085)\end{array}$ \\
\hline BUSH & & $\begin{array}{l}-0.552 * * * \\
(0.0026)\end{array}$ & & $\begin{array}{l}-0.369 * * * \\
(0.0204)\end{array}$ \\
\hline Constant & $\begin{array}{l}0.921^{* * *} \\
(0.0094)\end{array}$ & $\begin{array}{l}0.863 * * * \\
(0.0054)\end{array}$ & $\begin{array}{l}1.325^{* * *} \\
-0.475\end{array}$ & $\begin{array}{l}1.024^{* *} \\
-0.442\end{array}$ \\
\hline Observations & 23,040 & 23,009 & 2,087 & 2,087 \\
\hline R-squared & 0.775 & 0.924 & 0.071 & 0.198 \\
\hline
\end{tabular}

See Tables 1 and 2 for variable definitions. The omitted category is a white voter, between the ages of 35 and 64, who rents his or her home, and does not have a college degree.. Standard errors are reported in parentheses. This Table reports estimates of equations (6) and (7) in the text. County fixed effects are included in each regression. 
Table 6: Voting and Survey Regressions on Support for High Speed Rail

\begin{tabular}{|c|c|c|c|c|}
\hline VARIABLES & PCT_1A_Y & PCT_1A_Y & SUPPORT_HSR & SUPPORT_HSR \\
\hline $\operatorname{lnINC}$ & $\begin{array}{l}-0.0305^{* * *} \\
(0.0018)\end{array}$ & $\begin{array}{l}0.00998^{* * *} \\
(0.0013)\end{array}$ & $\begin{array}{l}-0.0643^{* * *} \\
(0.017)\end{array}$ & $\begin{array}{l}-0.0512^{* * *} \\
(0.017)\end{array}$ \\
\hline COLLEGE & $\begin{array}{l}0.166^{* * *} \\
(0.0036)\end{array}$ & $\begin{array}{l}0.0394^{* * *} \\
(0.0026)\end{array}$ & $\begin{array}{l}0.0705^{* * *} \\
(0.025)\end{array}$ & $\begin{array}{l}0.0524^{* *} \\
(0.025)\end{array}$ \\
\hline BLACK & $\begin{array}{l}0.173 * * * \\
(0.0042)\end{array}$ & $\begin{array}{l}-0.00394 \\
(0.0031)\end{array}$ & $\begin{array}{l}0.131^{* * *} \\
(0.044)\end{array}$ & $\begin{array}{l}0.0983^{* *} \\
(0.044)\end{array}$ \\
\hline ASIAN & $\begin{array}{l}0.0518^{* * *} \\
(0.0030)\end{array}$ & $\begin{array}{l}0.0559 * * * \\
(0.0021)\end{array}$ & $\begin{array}{l}0.155^{* * *} \\
(0.043)\end{array}$ & $\begin{array}{l}0.143^{* * *} \\
(0.043)\end{array}$ \\
\hline OTHER & $\begin{array}{l}0.0134 * * * \\
(0.0046)\end{array}$ & $\begin{array}{l}0.00387 \\
(0.0032)\end{array}$ & $\begin{array}{l}0.0562 \\
(0.034)\end{array}$ & $\begin{array}{l}0.0425 \\
(0.034)\end{array}$ \\
\hline HISP & $\begin{array}{l}0.128 * * * \\
(0.0033)\end{array}$ & $\begin{array}{l}0.0270 * * * \\
(0.0024)\end{array}$ & $\begin{array}{l}0.0782 * * \\
(0.033)\end{array}$ & $\begin{array}{l}0.0561 * \\
(0.033)\end{array}$ \\
\hline YOUNG & $\begin{array}{l}0.0422 * * * \\
(0.0046)\end{array}$ & $\begin{array}{l}0.0410^{* * *} \\
(0.0033)\end{array}$ & $\begin{array}{l}0.00169 \\
(0.031)\end{array}$ & $\begin{array}{l}-0.0047 \\
(0.031)\end{array}$ \\
\hline OLD & $\begin{array}{l}0.0181^{* * *} \\
(0.0046)\end{array}$ & $\begin{array}{l}0.00408 \\
(0.0032)\end{array}$ & $\begin{array}{l}-0.104^{* * *} \\
(0.029)\end{array}$ & $\begin{array}{l}-0.0924^{* * *} \\
(0.029)\end{array}$ \\
\hline HOMEOWN & $\begin{array}{l}-0.0937 * * * \\
(0.0024)\end{array}$ & $\begin{array}{l}-0.0573^{* * *} \\
(0.0017)\end{array}$ & $\begin{array}{l}-0.0691 * * \\
(0.027)\end{array}$ & $\begin{array}{l}-0.0715^{* * *} \\
(0.027)\end{array}$ \\
\hline lnDISTANCE & $\begin{array}{l}-0.0319 * * * \\
(0.0007)\end{array}$ & $\begin{array}{l}-0.0076^{* * *} \\
(0.0005)\end{array}$ & & \\
\hline lnDENSITY & $\begin{array}{l}0.00618^{* * *} \\
(0.0003)\end{array}$ & $\begin{array}{l}0.00274^{* * *} \\
(0.0002)\end{array}$ & & \\
\hline BUSH & & $\begin{array}{l}-0.464^{* * *} \\
(0.0030)\end{array}$ & & $\begin{array}{l}-0.151^{* * *} \\
(0.026)\end{array}$ \\
\hline Constant & $\begin{array}{l}0.728^{* * *} \\
(0.0090)\end{array}$ & $\begin{array}{l}0.679 * * * \\
(0.0063)\end{array}$ & $\begin{array}{l}1.389 * * * \\
(0.189)\end{array}$ & $\begin{array}{l}1.302^{* * * *} \\
(0.188)\end{array}$ \\
\hline Observations & 23,024 & 23,001 & 1,960 & 1,960 \\
\hline R-squared & 0.759 & 0.882 & 0.129 & 0.144 \\
\hline
\end{tabular}

See Tables 1 and 2 for variable definitions. The omitted category is a white voter, between the ages of 35 and 64, who rents his or her home, and does not have a college degree. Standard errors are reported in parentheses. This Table reports estimates of equations (6) and (7) in the text. County fixed effects are included in each regression. 
Table 7: Regressions of Proposition 23 Voting on Predicted Block-Group Vote Shares

\begin{tabular}{lll}
\hline VARIABLES & PCT_23_N & PCT_23_N \\
\hline PCT23N_Predicted & & \\
& $1.133^{* * *}$ & \\
PCT23N_Predicted_FE & $(0.005)$ & \\
& & $0.791^{* * *}$ \\
Constant & & $(0.005)$ \\
& $-0.385^{* * *}$ & $-0.0807^{* * *}$ \\
& $(0.005)$ & $(0.004)$ \\
Observations & & \\
R-squared & 23,009 & 23,009 \\
\hline
\end{tabular}

Standard errors in parentheses, ${ }^{* * *} \mathrm{p}<0.01,{ }^{* *} \mathrm{p}<0.05,{ }^{*} \mathrm{p}<0.1$

Note: The explanatory variables in this table were generated with coefficient estimates reported in Table 5, and the actual data by block group, and the following equations:

PCT23N_Predicted $=1.02-0.0308 * \operatorname{lnINC}+0.0374 *$ COLLEGE+0.0584*BLACK+0.0915*ASIAN +0.0394*OTHER$0.0201 *$ HISP $+0.0761 *$ YOUNG-0.0172*OLD-0.01*HOMEOWN+ 0.014*lnDISTANCE+0.00874*lnDENSITY$0.369 * \mathrm{BUSH}$

and

PCT23N_FE $=1.02-0.0308 * \operatorname{lnINC}+0.0374 * \mathrm{COLLEGE}+0.0584 * \mathrm{BLACK}+0.0915 * \mathrm{ASIAN}+0.0394 * \mathrm{OTHER}-$ $0.0201 *$ HISP $+0.0761 *$ YOUNG-0.0172*OLD-0.01*HOMEOWN $+0.014 * \ln D I S T A N C E+0.00874 * \operatorname{lnDENSITY}-$ $0.369 * \mathrm{BUSH}+$ county fixed effects 
Table 8: Fraction of U.S. population living at various distances from CBD, 1970-2010

\begin{tabular}{lllllllll|}
\multicolumn{1}{c}{} & $0-5$ & $5-10$ & $10-15$ & $15-20$ & $20-25$ & $25-30$ & $30-35$ & $>35$ \\
\cline { 2 - 10 } 1970 \\
1980 & 0.316 & 0.256 & 0.153 & 0.095 & 0.063 & 0.043 & 0.024 & 0.050 \\
1990 & 0.267 & 0.239 & 0.157 & 0.103 & 0.072 & 0.051 & 0.029 & 0.083 \\
2000 & 0.203 & 0.193 & 0.137 & 0.092 & 0.066 & 0.047 & 0.029 & 0.233 \\
2010 & 0.187 & 0.192 & 0.142 & 0.098 & 0.070 & 0.050 & 0.031 & 0.230 \\
\cline { 2 - 10 } & 0.169 & 0.188 & 0.146 & 0.102 & 0.073 & 0.052 & 0.034 & 0.235 \\
\hline
\end{tabular}

Each row sums to 1. 